MANUFACTURING

DECLINE 



\title{
MANUFACTURING DECLINE
}

\author{
HOW RACISM AND THE \\ CONSERVATIVE MOVEMENT \\ CRUSH THE AMERICAN RUST BELT
}

JASON HACKWORTH 


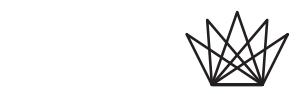

Columbia University Press

Publishers Since I893

New York Chichester, West Sussex

cup.columbia.edu

Copyright (C) 2019 Columbia University Press

All rights reserved

A complete cataloging-in-publication record is available from the

Library of Congress.

ISBN 978-o-23I-I9372-6 (cloth: alk. paper)

ISBN 978-o-23I-I9373-3 (trade pbk.)

ISBN 978-o-23I-55047-5 (e-book)

LCCN 2019010795

Columbia University Press books are printed on permanent and durable acid-free paper.

Printed in the United States of America

Cover design: Noah Arlow

Cover image: Abandoned House, Detroit. (C) Kevin Bauman 